Acta Poetica $32 \cdot 2$

JULIO-DICIEMBRE

$2011(115-143)$

\title{
Medea en los libros de caballerías hispánicos: libros, mito y ejemplaridad
}

\author{
Axayácatl Campos García Rojas
}

En este artículo se hará un estudio y análisis de la presencia de Medea en los libros de caballerías castellanos; se examinará el tratamiento que dio al personaje y sus funciones al interior de los textos. Se buscará considerar a Medea no solo como un referente, una simple presencia o una alusión, sino prácticamente como un motivo literario característico del género. Varias son las obras caballerescas que cuentan con la presencia de Medea bajo las significativas circunstancias señaladas, pero sobre todo se atenderá a libros de caballerías como las Sergas de Esplandián (1504), Lisuarte de Grecia (1514), Floriseo (1516), Polindo (1526), Baldo (1542), Belianís de Grecia (1547), El Cavallero del Febo (1555) y Espejo de príncipes y caballeros. Parte III (1588).

Palabras clave: Medea, siglo xvi, libros de caballerías, mito, ejemplaridad.

This paper deals with Medea as a character. Her role in Castilian romances of chivalry, her description, along with different portraits found in the genre. Medea is considered not just as a reference, a simple presence or an allusion, but rather as practically a literary motif characteristic of the genre. There are several chivalrous works which include Medea as aforementioned, but the paper will focus on las Sergas de Esplandián (1504), Lisuarte de Grecia (1514), Floriseo (1516), Polindo (1526), Baldo (1542), Belianis de Grecia (1547), El Cavallero del Febo (1555) and Espejo de príncipes y caballeros. Parte III (1588). 
Keywords: Medea, 16th Century, books of chivalry, myth, exemplarity.

Fecha de recepción: 11 de marzo de 2010

Fecha de aceptación: 18 de junio de 2010 
Axayácatl Campos García Rojas

Facultad de Filosofia y Letras

Universidad Nacional Autónoma de México

\section{Medea en los libros de caballerías hispánicos: libros, mito y ejemplaridad ${ }^{1}$}

Los libros de caballerías nutrieron sus páginas y anécdotas con materiales procedentes de variadas tradiciones y, asimismo, con el influjo de diversos géneros. Filtrada por el pensamiento medieval, la materia clásica llega a la narrativa caballeresca hispánica como una rica y poderosa fuente de modelos literarios, personajes, motivos y formas. Es precisamente el tratamiento que se dio a esa materia un aspecto fundamental que todavía es preciso estudiar en las obras de ficción caballeresca, ya inmersas plenamente en la Edad de Oro española.

Del enorme reparto caballeresco que recupera los nombres, los dioses y los héroes clásicos, la presencia de Medea es profundamente significativa como un personaje asociado a la magia y a las mujeres intensamente enamoradas. Medea constituye un referente prácticamente indispensable, que llega a la narrativa caballeresca cargado de toda la tradición grecolatina y que durante el Medioevo y el Renacimiento adquirió una nueva significación.

${ }^{1}$ Quiero manifestar mi agradecimiento al Dr. Josep Lluís Martos (Universitat d'Alicant) por los comentarios y las sugerencias que me hizo para la elaboración final de este artículo. 
En este artículo se hará un análisis de la presencia de Medea en los libros de caballerías castellanos, del tratamiento que se le dio y de sus funciones al interior de los textos. Se buscará considerar a Medea no solo como referente, simple presencia o alusión, sino como un motivo literario característico del género. Se atenderá específicamente a obras como las Sergas de Esplandián (1504), Lisuarte de Grecia (1514), Floriseo (1516), Polindo (1526), Baldo (1542), Belianís de Grecia (1547), El Cavallero del Febo (1555) y Espejo de príncipes y caballeros. Parte III (1588).

Medea, hija de Eetes, rey de la Cólquide, tras haber sido flechada por Eros queda irremisiblemente enamorada ex visu de Jasón (Alvar, "Amor de vista" y "Li occhi"; Ynduráin, "Enamorarse de oídas”). Este amor será el motor definitivo de la joven para acompañar al héroe en su travesía con los argonautas, ayudarle a conseguir el preciado vellocino de oro y casarse con él. De Medea se dice que fue sacerdotisa de Hécate, diosa telúrica de quien recibió el conocimiento mágico.

Las actuaciones de Medea en la literatura clásica ponen de manifiesto el enorme saber que poseía sobre artes adivinatorias y hechicería. Los diversos textos que hoy son fuente para estudiar al personaje la presentan como una mujer ambivalente, doble o contrastante. ${ }^{2}$ Su conducta es, además, resultado de grandes pasiones: el amor correspondido y luego el desamor, la venganza, la ira, la crueldad. Así, Medea emplea la magia en

${ }^{2}$ La figura de Medea debe rastrearse en obras como Las argonáuticas de Apolonio de Rodas (cantos III y IV), la Biblioteca mitológica de Apolodoro (libro I, 9), las Fábulas de Higinio (13-19, 22-27, 138), las Metamorfosis (VII, 1 ss.) y las Heroidas de Ovidio, los Persas de Esquilo y en sendas tragedias Medea de Eurípides y Séneca. Asimismo, fue antecedente fundamental la Historia destructionis Troiae de Guido de Columnis. Para la transmisión y reelaboración del personaje durante la Edad Media hispánica, véase las Summas de Historia Troyana de Leomarte (apud Gómez Redondo, Historia de la prosa medieval castellana I), la Corónica Troiana y la General estoria de Alfonso X (apud Gómez Redondo, Historia de la prosa medieval castellana II; Cuesta Torre, "La sección de Medea") y la prosa Srciu Medea de Joan Roís de Corella. 
pro o en contra de quienes son el receptáculo en turno de sus sentimientos (Highet, The Classical Tradition, 527). Sabemos que durante sus aventuras con Jasón y los argonautas no pocas veces empleó sus poderes para ayudar al héroe a salvar obstáculos, enfrentar maravillas y conseguir el áureo vellocino.

Medea puede realizar actos mágicos con diferente intención: tiene el poder benéfico de curar a los enfermos y la furia para urdir encantamientos que cumplan su venganza. Una vez de regreso en Corinto y casada con Jasón, este la abandona después de diez años para unirse a Glauce, hija de Creonte, rey de Tebas. En venganza, dio como regalo de bodas a la reina un manto y una corona envenenados, que ardieron en cuanto ella los usó.

Como vemos, la hechicera es capaz de matar mediante la magia con el propósito de alcanzar sus metas o satisfacer sus pasiones. Incluso, durante la ilícita escapatoria con Jasón y al huir de su padre, algunas versiones refieren que Medea dio muerte a su hermano Aspirto para distraer el camino del rey Eetes, y fue dejando caer uno tras otro los fragmentos del cuerpo en el río. Por irlos recogiendo, el rey demoró la persecución. No obstante, el mayor acto de crueldad que se le atribuye fue dar muerte a los hijos que concibió con Jasón y así vengarse de él. ${ }^{3}$

Esta es la imagen de Medea que llegó a la literatura medieval hispánica, con fuertes antecedentes que la vinculan con la magia, y con su uso positivo o negativo (Biglieri, "Medea y sus mundos"; Medea en la literatura). El conocimiento que posee de la nigromancia y su aplicación van desde el más afortunado don y el más benéfico apoyo hasta el peligro más aterrador y la amenaza más cruel. Desde esta perspectiva, Medea fue germen de desconfianza. Su magia es claramente rechazada por el

${ }^{3}$ Existen muchas versiones sobre el asesinato que Medea comete de sus hijos. En algunas obras se refiere que únicamente mató a los que tuvo con Jasón, pero sobrevivieron otros vástagos. Incluso se habla de Mérmero y Feres, quienes fueron brujos como ella. 
cristianismo y se consideró en franca oposición a los designios de la Providencia. No obstante, también estuvo rodeada por un halo de comprensión. Se le vio como una mujer que amó, quizá demasiado, capaz de advertir a otras acerca de la inconstancia amorosa de los hombres.

Esta doble y contrastante faceta configuró la imagen de Medea presente en los libros de caballerías del siglo XVI, la cual se consolidó a través de las obras medievales como motivo literario. Fernando Gómez Redondo, al hablar de las Summas de historia Troyana, señala

Cuando estos textos [romances narrativos franceses] penetran en la Península Ibérica aportan al pensamiento caballeresco autóctono un conjunto de matices enriquecedores de la ideología que, con posteridad, los libros de caballerías desarrollarían (Historia de la prosa, III, 1638).

El sistema argumental se torna más complicado, porque puesto que Jasón y Hércules intervienen en los acontecimientos, ello obliga a amplificar la narración con la vida de ambos, siempre con el propósito de integrar sus hazañas y desdichas en la mentalidad castellana del siglo xvi. Por tanto, la obtención del vellocino de oro se transforma en audaz aventura caballeresca, muy similar a las del Amadis desde el momento en que la resolución de la prueba obliga a superar los "acontecimientos de la isla de Colcas". Medea es dibujada conforme a los patrones del amor cortés, lo que justificará la inclusión de dos ovidianas y desoladas epístolas que descubrirán la infidelidad e inconstancia de "Jasón" (Gómez Redondo, Historia de la prosa, III, 1641).

En los libros de caballerías del Renacimiento, casi siempre se alude a la hija de Eetes de modo paralelo. No se trata de un personaje principal en la acción narrativa, pero sí está presente desde lo remoto, lo mítico y lo legendario. Es prácticamente solo una mención determinante. Podemos reunir la caracterización 
que se hace de Medea y sus funciones en dos categorías relacionadas con la intención de su magia: positiva o negativa; cada una, a su vez, atiende aspectos de tipo ejemplar y de referente histórico en el contexto de la narración.

\section{El poder mágico y los libros}

Desde los más tempranos libros de caballerías renacentistas y a lo largo del siglo xvI, los autores se vieron aparentemente seducidos por el carácter mágico de Medea, y sobre todo explotaron los aspectos positivos de ese conocimiento. La mujer de Jasón se consideró una autoridad de la materia y alusión de prestigio en lo relativo a encantamientos. La tradición clásica originó y construyó, a través del mito y la leyenda, una Medea que es hija de una ninfa y sacerdotisa de la diosa Hécate, lo que la vincula fuertemente con el mundo de lo oscuro, lo misterioso, lo mágico. Constituye, pues, una Morgana para las aventuras caballerescas, la versión femenina de la figura de Merlín, pero que llega a los libros de caballerías con todo el poder y la reputación que le confiere la Antigüedad grecolatina. Está vinculada directamente con Circe y Hécate, e incluso con Artemisa y Selene. Es mujer y maga, tiene pasiones, y además posee más poder que cualquier hada. Medea constituye la unión de todo lo mágico y sobrenatural, paralelo a los designios divinos. Sin embargo, es sospechosa, pues aunque evidentemente lleva a cabo acciones benéficas en la narración, persiste el temor a un posible peligro.

En este sentido, el mago que llegue a poseer los libros de Medea puede considerarse heredero o dueño de todo su saber. Así, en las Sergas de Esplandián (1504), al presentarnos a la infanta Melía - conocedora de astrología, ciencia y lenguas-, Garci Rodríguez de Montalvo nos dice que posee en su numerosa biblioteca algunos libros que pertenecieron a Medea: 
E [Melía] mandó hazer aquella cueva que cerca della veis, donde es su abitación; y después que a ella se vino y rompió sus vestiduras reales, nunca jamás quiso vestir otras, ni que persona alguna le fablasse, y come de las yervas y raízes dellas, según dizen passa su hedad de ciento y veinte años (557-558).

Y Esplandián dixo que en todo caso quería sacar los libros de la cueva; y luego entró dentro, [...] donde los libros estavan en tan gran número que él fue maravillado; y tomando cuantos llevar pudo los sacó fuera, y así lo hizo a los otros, aunque con gran trabajo, tardando gran rato. Cuando aquellos cavalleros los vieron, y las ricas guarniciones suyas de oro y plata y algunas piedras de gran valor, maravillávanse dello (603-604).

Más adelante en la misma obra, cuando Melía quiere liberarse de los griegos que la tienen capturada en Constantinopla y encantar igualmente al hada Urganda, pide que le sean llevados unos "libros que tienen figurada a Medea en las tapas", y que podemos atribuir como antigua posesión de la maga de la Cólquide. Libros que evidentemente emplea para formular un hechizo de proporciones espectaculares que, además, deja a Urganda fuera de las acciones en defensa del Cristianismo, justo cuando es más necesario subrayar el carácter mesiánico y la cruzada del protagonista Esplandián:

—Pues manda traer - dixo Melía - un libro que está entre los que me tomaste, que en somo de la una cubierta está Medea figurada con letras que su nombre señalan; y venido delante ti, quiero que veas lo que faré, y si por ventura no lo alcanças a saber, saberlo has para adelante.

—Eso luego se hará — dixo Urganda.

Y mandó a una donzella suya que lo truxesse, y luego fue traído. Mas en tanto que el libro vino, la infanta Melía tomó al rey Armato por la mano, y como que se solazavan por un prado, fabló con él sin que ninguno supiesse ni oyese lo que passava. E tornándose âssentar donde ante estava en el estrado de la Em- 
peratriz, tomó el libro y abriolo, y leyendo en él, començó a fazer unos signos y mirar contra el cielo y fablar entre sí (634).

En cuanto a los libros de Melía, tan atesorados por esta y la misma Urganda, Medea constituye un referente que les confiere prestigio mágico. Los libros despiertan la envidia, la codicia y la ambición en la benéfica hada Urganda. Poseer la biblioteca de Melía y por consiguiente los libros de Medea resguardados en ella significa ser dueño de un poder mágico formidable, ser el más poderoso de los magos (Cacho Blecua, "La aventura creadora", 40). Incluso, el ansia de poder mágico lleva a la misma Urganda a protagonizar una "graciosa y cruda pelea / que ambas las magas a manos hazían, / donde las uñas por armas suplían, / Cuando Medea topó con Medea" (Rodríguez de Montalvo, Sergas de Esplandián, 588).

En otro momento, Urganda no solo cede a la ambición nigromántica, sino que acepta el reto engañoso de Melía, quien fácilmente la encanta derrotándola con su magia, sobre todo con el poder de Medea, que evidentemente es más fuerte y ante el cual ambas magas resultan menores (Cacho Blecua, "La aventura creadora", 40).

El asunto de los libros mágicos adquiere también relevancia extraordinaria en el Lisuarte de Grecia (1514), cuando el sabio Alquife muestra a Lisuarte su biblioteca, donde resguarda importantes libros que lo respaldan como mago, pues le confieren su poder:

Les mostraron el castillo que muy gentil e bien labrado era, tal cual convenía para tan gran sabio como aquel; assí mesmo su librería, que fueron muy espantados de verla. Allí les mostró Alquife la profecía de Apolidón de la imagen de la corona [...]; assí mesmo les mostró en otro libro de la Donzella Encantadora la profecía de la espada que Esplandián ganara, y en otros libros de Apolidón la profecía del Arco de los Leales Amadores y de la espada e capilla de las flores, y cómo Amadís avía de ser 
encantado por Arcaláus e cómo Urganda lo avía de desencantar. Assí mesmo les mostró otra profecía del mesmo Apolidón, cómo el encantamento de Urganda avía de ser desfecho, aquel que hizo al rey Amadís e a sus hermanos en la Ínsula Firme [...]. Assí mesmo les mostró entre otros muchos libros con muchas e diversas profecías uno de la infanta Medea en que estava la profecía del rey e reina encantados que traían el yelmo e corona, pero no les quiso dezir la declaración d'ella por no estar complida (Lisuarte de Grecia; CORDE, 2008).

Los sabios presentes en los libros de caballerías, como Alquife en este caso, pueden considerarse intelectuales que adquieren, a través de un conocimiento libresco, sus habilidades en diversas disciplinas: las lenguas, las ciencias de los astros, la medicina, la magia. Nuevamente como en las Sergas de Esplandián, ya no solo es fundamental poseer un libro mágico, sino varios que conformen una biblioteca. Ese acervo está, pues, nutrido con obras creadas y libros de otros magos y hadas que antecedieron al presente mago en los quehaceres nigrománticos. Finalmente, la intertextualidad también incluye a los magos del género y se hace referencia a Urganda, Apolidón y Arcaláus del Amadís de Gaula, a la Donzella Encantadora de las Sergas y por supuesto a Medea, prácticamente como autoridad superior a todos ellos.

Semejante es un episodio en el Belianís de Grecia (1547) cuando el protagonista y sus compañeros entran al Castillo de Medea, fuertemente cerrado con poderosos encantamientos; finalmente logran el acceso gracias al sabio Fristón (Fernández, Belianis, II, 268, CORDE, 2008; Nasif, “Aproximación al tema de la magia", 42). Más adelante se señala que en un (padrón) "parescía estar escripta la profecía quel sabio Fristón en el libro de Medea hallara [...]" (Belianís, II, 459, CORDE 2008):

En el venidero tiempo quando mi subcessor y de mis máxicas artes, para consuelo y fauor de su más principal, sus artes trastor- 
nare, el inuencible castillo por mi saber fabricado por el suyo le será demostrado, donde encerrada la domadora de los más fuertes con vencimiento de mis guardas y esparzimiento de las contrarias sangres, después ayuntadas para remate de sus mayores vitorias, el remedio de su mayor amigo le será comunicado con el premio de sus más duidos premios, donde la esperiencia de su mayor valor y lealtad, de todo punto entre los mortales será conoscida (Belianis, II, 456, CORDE 2008; Nasif, “Aproximación al tema de la magia", 42).

Nuevamente vemos cómo la posesión de los libros de Medea y la capacidad para leer y desentrañar el sentido de sus palabras tienen significativa importancia para el prestigio y las habilidades de los magos. Asimismo, en la profecía que Fristón logra comprender se hace evidente la superioridad mágica de Medea, manifiesta cuando el mismo mago admira el castillo fabricado por ella y luego también se lamenta y le reprocha el ser tan poderosa que prácticamente es invencible:

Muy marauillado començó a contemplar en particular toda la obra y forma del castillo, que era de la forma que agora oyréys:

El castillo se mostraua estar asentado en aquella muy alta y llana sierra que vos deximos, con número de más de treynta torres tan altas que con el muy alto cielo su altura parescían comunicar, adornadas y fabricadas de piedras y jaspes tan reluzientes que como el sol por la mañana en ellas diesse, de todo punto no se dexaua ver. Auía de torre a torre, trecho de vn pequeño tiro de arco, las quales todas parescían ceñirse de vn tan alto y almenado muro que sólo aquél, sin defensa alguna que dentro estuuiesse, era inespunable [...].

Muy espantado quedó el sabio Fristón, viendo el admirable edificio del castillo y conosciendo por su saber las grandes fuerças que dentro estauan, a las quales ni su saber ni otro encantamiento alguno podía nuzir, teniendo por impossible que ninguna valentía, esfuerço ni coraçón humano a las acabar bastasse, con grandes exclamaciones contra Medea començó a dezir: 
— $\mathrm{O}$ señora, principio y fin de las máxicas artes y domadora de las infernales Furias! No sé por qué con tan dolorosos trabajos tal esperiencia quisistes hazer, saluo si el premio de lo que por ello se alcança, en acatamiento del que lo gozare no fuere tenido por mayor. ¡O príncipe Perianeo! Por cierto remedio que con tantos peligros auéys de alcançar, no me parece que cabe en buena amistad procurárosle, pero como todo se deua a conseruar vuestra vida, la qual si la señora de vuestro coraçón os fuesse lleuada, conozco sería impossible que la pudiéssedes sostener, todavía procuraré traer aquí aquélla de quien tanta noticia tanto tiempo antes la sabia Medea tuuo para su mayor gloria (Belianis, II, 459, CORDE 2008; Nasif, “Aproximación al tema de la magia", 42-43).

La autoría mágica es, además, un elemento que constituye y nutre el poder y el prestigio de Medea. Así, en el Lisuarte de Grecia se ensalza la figura de la hechicera clásica a través de sus actos pasados, que dejaron huella en el presente de la ficción narrativa. La mujer de Jasón, en un despliegue de habilidades mágicas, hace prácticamente una autoalabanza y se nombra la autoridad de la materia:

E leyendo [en un rótulo] las letras, dezían assí:

Yo, la infanta Medea, engendrada de los rayos del sol, sierva de los mis siete dioses que los cielos rodean, señora de todas las mágicas y artes de encantamientos en tanta manera que alcancé a saber todo lo que después de mis días vendrá, porque en mis tiempos no ovo nadie que igualasse a mi saber, ni después de mí vendrá, por mi memoria fize y obré con mis artes el presente encantamiento. Esto hize yo en este príncipe e infanta, porque en mis tiempos ninguno en amar se les igualó, ni después d'ellos vendrá hasta que aquel cavallero venga que en bondad y valentía por fuerça de armas y de amores gane lidiando con él el yelmo que el cavallero trae. Esto porque passará en bondad d'armas a todos los que antes d'él fueron (Lisuarte de Grecia, 209; CORDE 2008). 
En definitiva, las palabras de los personajes mismos dejan también testimonio y admiración de la magia y el poder de la hechicera: "Todos dezían que grande avía sido el saber de Medea y que era el más fermoso encantamiento que nunca vieran" (Lisuarte de Grecia, 210; CORDE 2008).

La relación de Medea con los libros se vincula con el tópico del sabio cronista, relator ficticio de los hechos narrados o al menos, como es su caso, depositaria y protectora de los textos (Marín Pina, "El tópico de la falsa traducción"; "Motivos y tópicos caballerescos"). En el prólogo del Espejo de príncipes y caballeros. Parte III (1588), el autor, Marcos Martínez, refiere cómo llegaron a su poder los manuscritos donde se da cuenta de las hazañas del Cavallero del Febo. Martínez, como un personaje más de la saga y como caballero, participa en una aventura maravillosa donde no solo se enfrenta en combate singular con el malvado mago Selagio, enemigo de los griegos, sino que es ayudado por Lirgandeo y Artemidoro, benéficos sabios que también dieron cuenta por escrito de la historia. Así mismo, Medea había resguardado de las malas intenciones de Selagio el manuscrito que contiene la Tercera parte que se dispone a recontar:

Aquella gran sabia Medea, en todas las artes reina, por su sobrado saber hizo tanto que hurtó d'esta morada la primera y segunda parte de las hazañas d'estos ínclitos griegos, no pudiendo sacar más, porque como el Selagio alcançasse a saberlo, vino muy ligero de su espantable morada, queriendo encantar la gran sabia. Mas como ella lo entendiesse, no tuvo lugar de tomar más de la primera parte, y segunda d'esta grande historia. Y assí, cuando el Selagio vino, Medea era fuera d'esta morada, causando en el Selagio no poco enojo, proponiendo quedar él en persona por guarda, aunque algo consolado, por aver robado tan sólo las dos partes, a donde de sus grandes maldades no se haze mención, por ser el principio de su seguimiento, con los belicosos griegos, en el fuerte Claridiano y su primo Rosabel, 
de quien se haze mención en el principio de la tercera parte. Y porque no tornasse otra vez la gran sabia a hazer presa en la bella historia, donde serían notorias sus maldades, él proprio en persona quiso tener la primera guarda, pues tanto le iva en la defensa, quedando en la empresa muerto a manos de los famosos sabios, como viste en el principio d'esta aventura dándome a mí con su muerte libertad, dexando sin guardador la famosa vida d'estos altos príncipes (Martínez, Espejo de príncipes y caballeros).

En este episodio, parte de una de las obras más tardías del género (1588), se observa un desarrollo del personaje de Medea que acentúa su conducta protectora. Aquí la maga está fuertemente relacionada con la figura arquetípica del mago auxiliar, que de manera sobrenatural protege al caballero. ${ }^{4}$ Sin embargo, en esta obra la protección de Medea no tiene influencia directa en los personajes, ya que esa función corresponde a magos menores; para ella está reservado un papel más trascendente, vinculado precisamente a la existencia misma de textos, de los libros donde se relatan las aventuras. Medea, como personaje caballeresco, conserva las crónicas con sus poderes mágicos, y asimismo deviene en una autoridad configurada a partir de la materia libresca.

4 "La magia es un órgano vital para el desarrollo del relato, en tanto abastece a la ficción de determinados elementos que resultan imprescindibles para su supervivencia y desarrollo, como la presencia de encantamientos, objetos mágicos y magos ayudantes o adversarios del héroe, y actualiza el mundo ficticio al ponerlo en contacto directo con las claves de una realidad contemporánea" (Esteban Erlés, "Aproximación al estudio de la magia"). Abundante es la bibliografía en torno al arquetipo heroico y al mago o personaje sobrenatural que funge como protector del héroe; para ampliar este tema, ver Joseph Campbell, The Hero with a Thousand Faces, y para la relación de este asunto con el mago artúrico, Merlín, ver Alvar, El rey Arturo; Lacy, The New Arthurian y Lendo, El proceso de reescritura. Es también relevante la tesis inédita de Claudia Benítez ("La figura del mago"), donde hace un estudio de la figura del mago en la narrativa caballeresca renacentista, especialmente en la tercera parte del Espejo de príncipes y cavalleros. Para el tema de la magia en la narrativa caballeresca véase Nasif, "Aproximación al tema de la magia". 
Como se ha visto en los ejemplos anteriores, la imagen de Medea se vincula especialmente con el poder benéfico de su magia; sin embargo, en ella hay también una importante faceta relacionada con valores negativos. En los libros de caballerías áureos, aunque con menor frecuencia, se manifiesta esta característica y se hace alusión al poder limitado de la hechicera. En el Belianís de Grecia se menciona incluso al maestro de Medea, dejando así evidente que también ella es vencible y aún existe un mago superior: "Y esto pudo él bien hazer como aquel que fue maestro de Medea, sin que nadie ni aun ella se le ygualasse" (Belianís, I, 228, CORDE, 2008). De modo similar, en el Polindo (1526), la magia de Medea se ve mermada al no surtir efecto sobre la tristeza del protagonista:

Y así [Polindo] otras muchas cosas de dolor dezía con piadosas lágrimas mezcladas. E como así anduviesse con la abundosa tristeza que su coraçón tenía, entró por una espesa e cerrada floresta donde fermosos árboles estavan e olorosas rosas el campo adornando. De modo que el tal frescor con suaves cantos de las aves los tristes coraçones alegravan. Mas aunque el gran saber de Medea allí fermosos jardines fabricado oviesse ni con ornamento de la dulce música de Orfeo vestidos estuviesen, nunca vencer pudieron al portero del coraçón del leal don Polindo, que antes al pesar las abriera. Tanto que muchas vezes por que el frescor de aquella floresta a su apassionado ánimo con holgura no le venciese, muchas vezes quería aquel camino apartar e tomar otro que antes su pena acrecentasse que su tristeza aliviar pudiesse (Polindo, 109; CORDE 2008; Suárez, Polindo (Toledo, 1526), 17-18, 83).

Si bien aquí no se destaca el aspecto negativo de la magia de Medea ni sus efectos en perjuicio de alguien, sí se pone de manifiesto su ineficacia en ciertas circunstancias. De hecho, se relata que la magia se empleó para crear un maravilloso escenario con características de locus amoenus que fácilmente sería 
deleite para cualquiera, pero ante el dolorido estado de ánimo de don Polindo Medea fracasa. Con ello se pretende exaltar los sentimientos amorosos del caballero y cómo su curación no podría provenir de la magia, sino del mismo amor y de la persona amada.

\section{Referencia histórica-mítica}

Por otra parte, los autores de libros de caballerías usan a la maga Medea como una referencia histórica y mitológica. Gracias a ella y a los argonautas se cuenta con un recurso narrativo que dota a la ficción de un halo legendario y remoto. En el Floriseo (1516) de Fernando Bernal, el protagonista pregunta sobre la Ínsola Encantada, adonde acaba de llegar, y se le responde: "Dízese que una dueña que se llamava Medea la encantó grandes tiempos ha. E dizen que lo hizo porque su padre, el Rey, no saliesse tras ella cuando se huyó de su casa con Jasón" (Bernal, Floriseo, 186; CORDE 2008; Guijarro Ceballos, Floriseo, 28-29, 62). Evidentemente se reutiliza la anécdota del mito, que refiere cómo Medea pretendió demorar o impedir la persecución de su padre cuando escapó con Jasón de la Cólquide. La brutalidad del asesinato de su hermano Aspirto, no obstante, se transforma aquí en un espacio maravilloso, propiciador de aventuras:

Señor — dixo el maestre - , por esso se dize encantada, porque no ay hombre que pueda dar razón d'ella ni de su gente, si de la ribera d'ella no. E dízese que no ha avido hombre que entre más de media legua dentro d'ella. E dízense muchas cosas maravillosas d'ellas de que no ay entera sabiduría, porque unos dizen que esta tierra paresce que está siempre encendida e otros dizen que paresce que se hunde; e otros, que los árboles d'ella parescen allegar al cielo e luego abaxarse al abismo, e que con todo esto ella echa de sí un suave e fuerte olor. E que ay en ella infinita diversidad de colores de árboles e de frutos e que se 
oyen en ellas las bozes de los hombres, pero que no los pueden ver (Bernal, Floriseo, 186; CORDE 2008; Guijarro Ceballos, Floriseo, 28-29, 62).

La isla, pues, es un escenario incierto, ambivalente y contrastante, como la misma Medea. Como consecuencia, Floriseo siente rechazo por el lugar, y por tanto también por la injerencia que Medea tuvo ahí. Cuando el maestre Gesipo le refiere los orígenes mágicos de aquella geografía insular, el caballero definitivamente se muestra escéptico y repudia con firmeza la referencia a la maga y a los argonautas; considera que es una historia falsa o, en todo caso, falseada por quienes la relataron: ${ }^{5}$

Maestro, esso no se deve creer, porque en la verdad no ovo Jasón ni Medea; e si los ovo, no hizieron lo que d'ellos han escrito los poetas. E por esto no me digáis la historia de la isla ni de sus primeros pobladores, sino contadme qué gentes ay en ella e su manera de bivir, e si es sugeta a algún señor (Bernal, 186; CORDE 2008; Guijarro Ceballos, 28-29, 62).

Tenemos aquí un ejemplo del motivo ecdótico, donde se señala que una historia relatada por "poetas" o cronistas anteriores no es verdadera o no es la versión correcta (Campos García Rojas, "Galtenor cuenta"). Sin embargo, Floriseo tampoco ofrece una versión diferente que permita cotejar ambas y así obtener otra que resulte verdadera. La incredulidad del caballero sugiere una postura ante lo que representan Medea y sus poderes; después de todo, su actitud es congruente desde una perspectiva cristiana que rechaza la nigromancia.

Otra referencia a la historia de Medea está en el Baldo, cuando se menciona la anécdota del vellocino de oro en relación

\footnotetext{
${ }^{5}$ Para el tema de la isla, sus simbolismos y su carácter femenino, véase Alvar, "Mujeres y hadas"; Campos García Rojas, "Florisdelfa"; "Centros geográficos"; "La Ínsula"; Geografia y desarrollo del héroe, 52-58, y Tomé, La isla.
} 
con los signos del zodiaco para explicar la presencia del carnero en Capricornio y Aries:

\begin{abstract}
Adonde fingieron los poetas muchas cosas sobre estos signos y cómo estos animales fueron colocados en el cielo. El primero es el que tiene figura de carnero que se atribuye al mes de março, el cual dizen que fue d'esta manera colocado en el cielo porque Júpiter, en aquella temerosa batalla que intentaron los gigantes contra los dioses, donde Apolo se tornó en cuervo, Baco en cabrón, Diana en gata, Juno en vaca, Venus en pece, Mercurio en cigüeña, Júpiter en carnero, el cual fue después honrado en aquella figura de los de África porque, yendo un hijo de Júpiter por la arenosa Libia y aviendo perdido el camino, halló un carnero que le enseñó el camino y, pensando que era de su padre, hizo allí un templo que se llamó de Júpiter Hamón. Y esta figura fue puesta en el cielo. Otros dizen que era por el vellocino dorado del carnero que truxo Frixo, hermano de Heles, a Colcos que después tomó Jassón con ayuda y saber de Medea (CORDE 2008; Gernert, Baldo, 2000 y 2002).
\end{abstract}

Aquí está presente la variante de las “crónicas contrapuestas" del motivo ecdótico, pues los hechos de los argonautas y de cómo la magia de Medea ayudó a Jasón se suman a las referencias que constituyen otra versión de los hechos (Campos García Rojas, “'Galtenor'”).

\title{
3. Medea ejemplar
}

En la narrativa caballeresca, Medea también constituyó un recurso al servicio del docere con profundas raíces medievales. La referencia a ella tuvo un sentido ejemplar, tanto de conducta humana virtuosa como de una que no se debe imitar. La hija de Eetes ilustra actitudes deseables y positivas en una mujer del siglo XVI: valor, alegría, lealtad amorosa y buen consejo. Sin 
embargo, también se le emplea como ejemplo de mujer vengativa y cruel, cuyo fin resulta desastroso. En el Polindo, el autor de la obra emplea el tópico de la imposibilidad de la escritura para relatar algo con exactitud, haciendo referencia a varias parejas de enamorados y al placer que sintieron (Lucía Megías, De los libros de caballerías, 148). La lealtad amorosa de Medea la conduce incluso al asesinato de su propio hermano para poder permanecer junto al hombre que ama:

Arto loco sería yo, autor d'esta obra, si quisiera dezir el plazer que ovo don Claribeo. Ni el alegría que Héctor el Troyano sintió cuando las fuertes y temerosas batallas venció ni el plazer de su hermano Paris con la hermosa Elena ni Medea con su desseado Jasón, por quien ella mató a su hermano faziéndole pedaços por salvarse a sí y a su querido Jasón ni cuando la reina Dido tubo a su voluntad a Eneas ni el plazer de Eneas cuando casó Lavinia, fija del rey latino, ni cuando sojuzgó a todas las italianas ni cuando se encerrara la reina Iseo la Brunda con el esforçado Tristán de Leonís, ninguna alegría d'estas no se puede igualar con la del príncipe don Claribeo con tal mensaje (Polindo, 110; CORDE 2008, Suárez, Polindo (Toledo, 1526), 18).

En esta obra el protagonista menciona a Medea cuando este ve a Filestra, la doncella que le trae noticias de su amada. El caballero, entonces, enumera parejas de amantes famosos que se deleitaron y gozaron con la presencia del ser amado. Así, la maga es admirada y representa un ejemplo de mujer enamorada por la alegría que experimentó cuando estuvo en compañía de Jasón y cuando era amada por él:

Amiga Filestra, es tanta el alegría que vuestra vista me causa que ni el fermoso Paris cuando en sí poseyó a la fermosa Elena ni Medea cuando tuvo a Jasón ni Daymira a Ércules ni Plutón a Proserpina - aquel que, sin ella poder resistir, la hurtó-, el alegría qu'estos tenían no se compara con la mía en ser visitado 
de vós, en quien mi vida está dependiendo e mi remedio de mi vida me viene (Polindo, 57; CORDE 2008; Suárez, Polindo (Toledo, 1526), 23).

Por su parte, la misma doncella dolorida se lamenta porque la diosa Venus y su hijo Cupido no la favorecen con el amor de don Polindo, así como en otros momentos sí beneficiaron a otras parejas de amantes. Estos dioses, incluso, prefirieron apoyar a la sabia Medea que a la doncella. El lamento femenino por la ausencia y la aparente crueldad del hombre amado recuerda las Heroidas de Ovidio, y eso también lo vincula directamente con el personaje de Medea:

Mi desventura lo causa $¡ \mathrm{O}$, cruel y desleal don Polindo! ¿Esto era lo que yo de ti oía? ¿Esto es lo que los Doze de la Fama de ti han publicado? ¿Estas son las virtudes que en ti clausas estavan? La piedad que de ti se oye es lo que conmigo usas, en mi muerte codiciar con desdenes que a mi amor has fecho $¡ \mathrm{O}$, amor! ¡O, niño Cupido ciego! ¡O, fermosa diosa Venus! ¡Cuán mal mirastes a quien vuestra dorada flecha tirastes! Pues con ella pensastes de me dar alegría e me dais la desastrada muerte e sin ventura fin. ¡Cómo mejor distes vuestros agradables favores a la fermosa e sabia Medea e a la linda reina Elena e a Paris, su amante! Mas a mí, que la alegría me falta, el favor me huye. La muerte para dar descanso a mis passiones no me quiere oír. Mi entero juizio me fallece, la razón me repugna, mi coraçón se faze entre sí pedaços, que del dolor muero. De manera que en el mundo nasció donzella tan sin ventura como yo, captiva. Y como captiva bivo e bivo desesperada y con gran afligimiento de mí mesma. ¡Felises, Felises! No heches la culpa al bueno don Polindo, estremado sobre cuantos biven en el orbe mundano, salvo a tu desastrada fortuna, qu'en los golfos más peligrosos del mar te acosta, desconfiada de bonança que avenirte pueda. Que si bien lo consideras, en aquella parte navegas donde todos son anegados con la dulce canción de la falsa serena. Así yo captiva fui con falsos plazeres halagada, dándome esfuerço 
a que viniese (Polindo, 36, CORDE 2008, Suárez, Polindo (Toledo, 1526), 23).

Este fragmento pone de manifiesto la poderosa influencia de la ficción sentimental en los libros de caballerías y cómo constituye para el género una fuente fundamental y rica en cuanto a estrategia narrativa.

Además, Medea es mencionada como ejemplo respetable de quien posee y sabe dar buen consejo: "Que si Jasón ganó el vellocino dorado no fue por esfuerço, salvo por el buen consejo que la sabia Medea le dio de cómo se avía de aver en aquella aventura" (Polindo, CORDE 2008). Después de todo y pese a las intenciones de Medea, las recomendaciones que dio a Jasón lo condujeron al éxito de la empresa.

Por otro lado y con respecto al carácter negativo de Medea como exemplum ad contrarium, se enfatiza su relación con el sentimiento de venganza y crueldad. En el Belianís de Grecia, ella edifica un encantado castillo para vengarse del cruel abandono de Jasón:

Pues en este tiempo que vos dezimos, en la corte acaesció vna auentura tan estraña y peligrosa que no sólo en doblado pesar y tristeza la boluió, mas los ánimos[s] de los fortíssimos príncipes don Belianís y Perianeo fueron turbados de tal suerte que oluidados los pensamientos que cada vno dellos tenía, de cómo podrían auer en su poder a la princesa Florisbella, fueron bueltos en otros nueuos y más penosos cuydados, teniéndola por perdida, para lo qual auéys de saber que al tiempo que la penosa Medea estuuo aguardando penada por los amores de su desabrido cauallero Jasón, viendo su tan contina tardança y oluido, procuró de saber por sus artes, la causa de su oluido y hallando que él seguía los amores de la bella Tiandra, no muy lexos de la Baxa Armenia, enojada y llena de la cruel ponçoña de los zelos, la quiso dar la muerte, mas desseando darle mayor pena que la misma muerte, por su saber, encima de la gran Suria, hizo vn 
encantado castillo tal que la fortaleza del su Jasón no bastasse a le deshazer, el qual quiso que durasse hasta tanto que vna profecía suya, que entre sus libros dexó escripta, se cumpliesse en fauor del más estremado cauallero que hasta entonces vuiesse auido, donde en continos tormentos y congoxas puso a la bella Tiandra (Fernández, Belianís de Grecia, I, 207, CORDE 2008; Nasif, “Aproximación al tema de la magia”, 42-43).

Finalmente, en la tercera parte del Espejo de príncipes y cavalleros, Medea es ejemplo de conducta vengativa y cruel y se le coloca junto a Progne, quien como la maga de la Cólquide dio muerte a su propio hijo para vengarse de Tereo, su marido (Martínez, Espejo de príncipes y caballeros, Libro III) ${ }^{6}$. En la obra, la dama Polinarda resulta tan rigurosa con sus pretendientes que supera en crueldad a las mismas Medea y Progne:

Entró en el aposento de la hermosa Polinarda: a la cual según me dixo halló vestida de luto, y en frecuente llanto. De lance en lance parlando, la vino a forçar que preguntasse por mí. Respondió, que estava con el contento que está quien espera triste muerte:

-y quitele esta carta que le hallé encima de un escriptorio, y viendo que era para vuestra alteza, la traigo por que se queme, antes que acontezca más daño.

Súpola tan bien vender, y con tan buena persuasión, que no sospechó la dama cosa de que él supiesse algo. Díxola fingiendo alguna ocasión, por dársela para que la leyesse. Hízolo, pues d'ello vino a resultar la muestra de más crueldad que cuantas ha havido en el mundo. Medea, y Progne no pueden llamarse crueles viviendo ahora Polinarda, que con su respuesta mostró

${ }^{6}$ En El Cavallero del Febo (1555), primera parte del ciclo de Espejo de príncipes y caballeros, Diego Ortúñez de Calahorra introduce un personaje llamado Medea que, si bien no tiene relación aparente con la maga de la materia clásica, sí se trata de una mujer cuyo móvil en la obra es precisamente la venganza. Desea y busca quién vengue la muerte de su padre Rajartes (v. 113, Martínez, 120-125). 
tenerlas ventaja: y oídla, porque os enteréis lo que puede la ira lançada en una muger.

Sacola, y no sin sospiros, acompañados de muchas lágrimas la leyó assí:

Respuesta de Polinarda.

En dos estremos me puso tu carta cruelíssimo cavallero, el mayor que ha nacido, uno, que no me causava poco daño, y era persuadirme a tener letra de quien me quitó la vida, con dar la muerte a aquel desdichado príncipe: otro que no es menos que muerte, verme forçada para responderte, porque disimular con tu carta fuera darte ocassión para que entendieras gustava de lo que pides, y venida al menor daño, aunque es muy mayor que muerte, no se juzgará a crueldad nueva, usarla yo con ${ }^{74 v a}$ quien la ha executado conmigo. Mi vista no ay que dessearla, si ha de ser para darte contento, que quien me lo quitó a mí, no ay para qué me lo pida, y pues diste la muerte al que no la merecía, mereciéndola tú, y la más cruel: no ay sino que se execute. No te puedo dessear vida, para acabar: quien anda procurando tu muerte, por consolarse (Martínez, Espejo de príncipes y caballeros, Libro III, Cap. 28, fol. 74rb).

En conclusión, Medea en los libros de caballerías hispánicos del siglo XVI no solo fue un referente cultural heredado de la tradición grecolatina, sino que su presencia constituyó un rico y poderoso recurso narrativo, con posibilidades evocadoras de un pasado remoto, mágico y maravilloso, mítico... Pero también la maga de la Cólquide fue una figura ejemplar, que permitió a los autores ilustrar modos de conducta deseables o reprobables, especialmente en su público femenino. De Medea se tomó y recreó una perspectiva doble que la presentaba como un personaje inestable y temible, vengativo, cruel y digno de desconfianza por el uso que pudiere dar a sus poderes mágicos. No obstante, también se le consideró el ejemplo de una mujer engañada que padeció la inconstancia amorosa de los hombres; una mujer que reunía grandes y extremas pasiones. 
Durante el Medioevo y el Renacimiento hispánicos, Medea fue configurada como la autoridad nigromántica, un modelo ideal e imitable para los magos, las hadas y los sabios encantadores que en la subsecuente narrativa caballeresca del Siglo de Oro hacían su aparición como enemigos o auxiliadores del héroe. La trascendencia de Medea, más allá de su crueldad y sabiduría ejemplares, reside precisamente en el discurso que la presenta como una mujer completa: con sus vicios y virtudes, con su mesura y su codicia, con su amor formidable y apasionado y su odio irrefrenable. Se trata de una mujer temible y deseable; una mujer que definitivamente se instaló de modo indispensable en la narrativa caballeresca y en la literatura española, para recordarnos siempre el fascinante y múltiple poder de las mujeres; poseedoras, como Medea, de libros invaluables, saberes insospechados y reveladores conocimientos; audaces consejos para alcanzar el mítico vellocino de oro y tenaces conductas para lograr sus objetivos a toda costa.

\section{REFERENCIAS}

Alvar, Carlos, "Amor de vista, que no de oídas", en Homenaje a A. Zamora Vicente, Madrid, Castalia, 1991, III, 13-24.

Alvar, Carlos, "Mujeres y hadas en la literatura medieval", en Evolución narrativa e ideológica de la literatura caballeresca, María Eugenia Lacarra (ed.), Bilbao, Universidad del País Vasco, 1991, 21-33.

Alvar, Carlos, El rey Arturo y su mundo. Diccionario de mitología artúrica, Bilbao, Universidad del País Vasco, 1991.

Alvar, Carlos, "Li occhi in prima generan l'amore: consideraciones sobre el concepto de 'amor' en la poesía del siglo XIII', en Il Duecento: Actas del IV Congreso Nacional de Italianistas (Santiago de Compostela 24-26 de marzo de 1988), Santiago de Compostela: Universidad, 1989, 9-18 (Cursos e congresos da Universidade de Santiago de Compostela, 60). 
Apolodoro, Biblioteca mitológica, Madrid, Gredos, 1985.

Benítez García, Claudia, "La figura del mago en Espejo de príncipes y caballeros. Parte III: tipos y funciones", Tesis de licenciatura en Lengua y Literaturas Hispánicas, México, Universidad Nacional Autónoma de México, Facultad de Filosofía y Letras, 2007. Bernal, Fernando, Floriseo, Javier Guijarro Ceballos (ed.), Alcalá de Henares, Centro de Estudios Cervantinos, 2003 (Los libros de Rocinante, 14).

Biglieri, Aníbal, Medea en la literatura española medieval, La Plata, Fundación Decus, 2005.

Biglieri, Aníbal, "Medea y sus mundos posibles", Revista de Poética Medieval 2, 1998, 49-77.

Cacho Blecua, Juan Manuel, "La aventura creadora de Garci Rodríguez de Montalvo: del Amadís de Gaula a las Sergas de Esplandián", en Textos medievales: Recursos, pensamiento e influencia. Trabajos de las IX Jornadas Medievales, Concepción Company, Aurelio González y Lillian von der Walde (eds.), México, El Colegio de México / Universidad Autónoma Metropolitana / Universidad Nacional Autónoma de México, 2005, 15-50 (Publicaciones de Medievalia, 32).

CAmpbell, Joseph, The Hero with a Thousand Faces, London, Fontana Press, HarperCollins Publishers, 1993 [1a ed. Princeton, University Press, 1949].

CAmpos García Rojas, Axayácatl, "Centros geográficos y movimiento del héroe: de la Ínsola Firme a la Peña Pobre en el Amadís de Gaula", Voz y Letra: Revista de Literatura, 11: 2, 2000, 3-20.

Campos García Rojas, Axayácatl, "Florisdelfa: un episodio insular en Tristán de Leonís desde una interpretación de sus elementos geográficos y la magia", en "Quien hubiese tal ventura": Medieval Hispanic Studies in Honour of Alan Deyermond, Andrew M. Beresford (ed.), London, Department of Hispanic Studies, Queen Mary \& Westfield College, 1997, 237-245.

Campos García Rojas, Axayácatl, "'Galtenor cuenta..., pero Lirgandeo dize...': El motivo ecdótico en los libros de caballerías hispánicos", en Amadís de Gaula. Quinientos años después. Estudios en homenaje a Juan Manuel Cacho Blecua, María Carmen 
Marín Pina y José Manuel Lucía Megías (eds.), con la colaboración de Ana Carmen Bueno Serrano, Alcalá de Henares, Centro de Estudios Cervantinos, 2008, 117-132.

Campos García Rojas, Axayácatl, Geografía y desarrollo del héroe en "Tristán de Leonis " y "Tristán el Joven", pról. María Luzdivina Cuesta Torre, Alacant, Universitat, 2002.

Campos García Rojas, Axayácatl, "La Ínsula del Ploto en Tristán de Leonís y la construcción de un legado: el modelo ejemplar de los Reyes Católicos", en "Fechos antiguos que los cavalleros en armas passaron": estudios sobre la ficción caballeresca, Julián Acebrón Ruiz (ed.), Lleida, Edicions de la Universitat de Lleida, 2001, 75-96 (Ensayos / Scriptura, 11).

Columnis, Guido de, Historia destructionis Troiae, Nathaniel Edward Griffin (ed.), Cambridge, Mass., The Mediaeval Academy of America, 1936.

Corpus diacrónico del español (CORDE) <http://www.rae.es $>$ [fecha de consulta: julio, 2008].

Cuesta Torre, María Luzdivina, "La sección de Medea y su interpretación en la General Estoria", Troianalexandrina: Anuario sobre literatura medieval de materia clásica, 7, 2007, 187-215.

Esquilo, Tragedias, intr., trad. y notas de Enrique Ángel Ramos Jurado, Madrid, Alianza, 2001.

Esteban ErLÉs, Patricia, “Aproximación al estudio de la magia en los primeros libros del ciclo amadisiano", en De la literatura caballeresca al "Quijote", Juan Manuel Cacho Blecua (coord.), Ana Carmen Bueno Serrano, Patricia Esteban Erlés y Karla Xiomara Luna Mariscal (eds.), Zaragoza, Prensas Universitarias de Zaragoza, 2007, 185-199 (Humanidades, 61).

EuRíPIDEs, Cuatro tragedias y un drama satírico: Medea, Troyanas, Helena, Bacantes, Cíclope, ed. Antonio Melero Bellido, Madrid, Akal, 1990.

Garibay K., Ángel María, Mitología griega: Dioses y héroes, México, Porrúa, 1986.

Gernert, Folke, Baldo (Sevilla, Dominico de Robertis, 1542), Alcalá de Henares, Centro de Estudios Cervantinos, 2000 (Guías de lectura caballeresca, 38). 
Gernert, Folke, Baldo, Alcalá de Henares, Centro de Estudios Cervantinos, 2002 (Los libros de Rocinante, 13).

Gómez Redondo, Fernando, Historia de la prosa medieval castellana. I: La creación del discurso prosístico: El entramado cortesano, Madrid, Cátedra, 1998.

Gómez Redondo, Fernando, Historia de la prosa medieval castellana. II: El desarrollo de los géneros. La ficción caballeresca y el orden religioso, Madrid, Cátedra, 1999.

Gómez Redondo, Fernando, Historia de la prosa medieval castellana. III: Los orígenes del humanismo. El marco cultural de Enrique III y Juan II, Madrid, Cátedra, 2002.

Guijarro Ceballos, Javier, Floriseo (Valencia, Diego de Gumiel, 1516), Alcalá de Henares, Centro de Estudios Cervantinos, 1999 (Guías de lectura caballeresca, 10).

Highet, Gilbert, The Classical Tradition: Greek and Roman Influences in Western Literature [1949], Oxford, University Press, 1976.

Higinio, Fábulas, trad. Santiago Rubio Fernández, Madrid, Gredos, 1997.

HöNIG, Susanna Ja Ok, "Algunas notas sobre las hadas, magas y sabias en las novelas de caballerías", en De la literatura caballeresca al "Quijote", Juan Manuel Cacho Blecua (coord.), Ana Carmen Bueno Serrano, Patricia Esteban Erlés y Karla Xiomara Luna Mariscal (eds.), Zaragoza, Prensas Universitarias de Zaragoza, 2007, 283-300 (Humanidades, 61).

Lacy, Norris J. (ed.), The New Arthurian Encyclopedia, London, St James Press, 1991.

LENDO, Rosalba, El proceso de reescritura de la novela artúrica francesa: La "Suite du Merlin", México, Universidad Nacional Autónoma de México / Facultad de Filosofía y Letras, 2003.

Lucía Megías, José Manuel, De los libros de caballerías manuscritos al "Quijote" Madrid, Sial ediciones, 2004 (Trivium. Biblioteca de textos y ensayo, 9).

Marín Pina, María Carmen, "El tópico de la falsa traducción en los libros de caballerías españoles", en Actas del III Congreso de la Asociación Hispánica de Literatura Medieval (Salamanca, 3 al 6 de octubre de 1989), María Isabel Toro Pascua (ed.), Salaman- 
ca, Biblioteca Española del Siglo xv \& Departamento de Literatura Española e Hispanoamericana, 1994, vol. I, 541-548.

Marín Pina, María Carmen, "Motivos y tópicos caballerescos", en Miguel de Cervantes, Don Quijote de la Mancha, vol. complementario, Francisco Rico (dir.), Barcelona, Instituto Cervantes / Crítica, $2^{a}$ ed. revisada, 1998, 857-902.

Martínez, Marcos, Espejo de príncipes y caballeros. Parte III, Axayácatl Campos García Rojas (ed.), Alcalá de Henares, Centro de Estudios Cervantinos [en prensa] (Los libros de Rocinante).

MARTos, Josep Lluís, "Medea i la confessió autobiogràfica com a prevenció contra els hòmens", en Fonts $i$ seqüència cronológica de les proses mitològiques de Joan Roís de Corella, Alacant, Universitat d'Alacant, Departament de Filologia Catalana, 2001, 190-213 (Biblioteca de Filologia Catalana, 10).

NASIF, Mónica, “Aproximación al tema de la magia en varios libros de caballerías castellanos, con referencia a posibles antecedentes literarios", en "Amadis de Gaula”. Estudios sobre narrativa caballeresca en la primera mitad del siglo XVI, Lilia Elda Ferrario de Orduna (ed.), Cassel, Reichenberg, 1992.

Nasif, Mónica, Belianís de Grecia de Jerónimo Fernández. Partes I y II (Burgos, Martín Muñoz, 1547), Alcalá de Henares, Centro de Estudios Cervantinos, 2006 (Guías de lectura caballeresca, 47).

Ovidio, Metamorfosis, Antonio Ruiz de Elvira (ed.), Madrid, Consejo Superior de Investigaciones Científicas, 1994.

Ovidio, Heroidas, Francisca Moya del Bano (ed.), Madrid, Consejo Superior de Investigaciones Científicas, 1986.

Polindo, Manuel Calderón Calderón (ed.), Alcalá de Henares, Centro de Estudios Cervantinos, 2003 (Los libros de Rocinante, 16).

RodAs, Apolonio de, Las argonáuticas, introd. trad. y notas de Mariano Valverde Sánchez, Madrid, Gredos, 1996.

Rodríguez de Montalvo, Garci, Sergas de Esplandián, Carlos Sainz de la Maza (ed.), Madrid, Castalia, 2003 (Clásicos Castalia, 272).

Roís De Corella, Joan de, Scriu Medea a les dones la ingratitud e desconexença de Jàson, per dar-los exemple de honestament viure, en Les proses mitològiques de Joan Roís de Corella, Josep Lluís Martos (ed.), pról. de Rafael Alemany Ferrer Alacant / 
Barcelona, Institut Universitari de Filologia Valenciana, Publicacions de l'Abadia de Montserrat, 2001, 207-236 (Biblioteca Manuel Sanchis Guarner, 55).

Ruiz de Elvira, Antonio, Mitología clásica, Madrid, Gredos, 1975. SÉNECA, Medea: Edición bilingüe, trad. Valentín García Yebra, Madrid, Gredos, 2001.

SuÁrez, Juan Luis, Polindo (Toledo, 1526), Alcalá de Henares, Centro de Estudios Cervantinos, 2004 (Guías de lectura caballeresca, 22).

Tomé, Mario, La isla: utopía, inconsciente y aventura: hermenéutica simbólica de un tema literario, León, Universidad, 1987.

YndurÁin, Domingo, "Enamorarse de oídas", en Serta philologica F. Lázaro Carreter natalem diem sexagesimum celebranti dicata, II: Estudios de literatura y crítica textual, Madrid, Cátedra, 1983, 589-603. 